\title{
Influential Marketing Strategies are Simultaneously Against the (use of) the Occupational Hospitalization by the BPJS Patients in Hospital Muhammadiyah University of Malang
}

\author{
Arief Churniawan', \\ Byba Melda Suhita ${ }^{2}$, \\ Yuly Peristiowati ${ }^{2}$ \\ ${ }^{1}$ Magister of Health Study \\ Program of Institut Ilmu \\ Kesehatan STRADA Indonesia \\ ${ }^{2}$ Lecturer of Institut Ilmu \\ Kesehatan STRADA Indonesia
}

Email:

arifkurniawan415@gmail.com

Received: October 12, 2019

Accepted : February 13, 2020

Published : May 11, 2020

\begin{abstract}
The aimed of this research to analyze marketing strategies take effect simultaneously against the (use of) the occupational hospitalization by the BPJS patients in hospital Muhammadiyah University of Malang. Quantitative research design that is crossectional. Research on variable i.e. the influence marketing strategies are simultaneously against and as the independent variable and the (use of) occupation hospitalization as the dependent variable BPJS. Population research i.e. whole health BPJS patients who underwent hospitalization on 15th October November 15, 2018. Samples taken by random sampling technique as much as 92 respondents. The data collected by the instruments and questionnaires processed in coding, editing, tabulating and scoring as well as tested with linear regression test. Linear regression results indicate that partially and the simultaneous there are shows a value of $\mathrm{p}=0,00<0.05$ so that ther is influence marketing strategies towards occupational (usage) of inpatient care by patients BPJS RS UMM Malang. R Square (R2) of 0.660 or $60.6 \%$ that shows contributions from independent variable marketing strategies (product, price, place, people, and processes), while the rest was $39.4 \%$ in influence by other factors that do not exist in this research model. Multiple correlation coefficient is used to measure the keeratan relationship between the dependent and independent variables. The results showed that the strategy of marketing (product, price, place, people, and processes) conducted by the managing of RS UMM exactly will affect the increase in occupasi or DRILL the patients. Process management efekstif, efficient and does not kink as well as facilitate the patient in obtaining health services can be one alternative reference patient in taking a decision to receive a health service. The existence of a negative perception by the patient about marketing strategy indicated that dissatisfaction received the patient and can make patients feel uncomfortable in accepting hospital service, so this affects patients in using the services of the hospital or hospital can move patients.
\end{abstract}

Keywords: Marketing strategies, occupational patient, hospital 


\section{INTRODUCTION}

Hospital Muhammadiyah University of Malang (RS UMM) based on Permenkes RI No. 340 Year 2010 about the hospital classification including type $\mathrm{C}$ hospitals with bed capacity as much as 138 fruit. The facilities at the Hospital University of Muhammadiyah Malang (RS UMM) form a clinic service consists of service specialist doctor (pediatrician, Lung specialist, a specialist in the disease, and some general surgery specialist Orthopedic, obstetrics and gynaecology specialist, a specialist skin and sex, clinical pathology specialist, specialist anaesthetic, eye specialists, ENT specialists, a nerve specialist, a specialist in Psychiatry) general practitioner services, dental services, IGD and ICU, one day care treatment of Haemorrhoids, and there is support in the form of examination of Radiology, laboratory, clinical, ultrasound and CT dimension 4 provides maternity, perinatology, a child with room amenities of comfortable treatments and thematically as well as operating room with modern technology.

Since January 1, 2014 the Government has enacted the National Healthcare System (SJKN) and the BPJS as governing body the national healthcare program. UMM hospital participating in the program by partnering with the BPJS on 1 January 2015 until now. Cooperation that intertwined is one marketing strategy (marketing) of RS. UMM. Health facilities that can establish a partnership with the BPJS were qualified health facilities in order to memenui the needs of medic a number of participants. Health facilities are deemed eligible for these health facilities in particular are recognized and have permission from the responsible government agencies in the field of health. Healthcare facilities as mentioned above according to the explanation of article 23 and paragraph (1) of the ACT SJSN include hospitals, physician practices, clinics, laboratoirum, pharmacies and other healthcare facilities.

According to the regulation of the Minister of health of the Republic of Indonesia Number 001 Year 2012 about Individual health services Referral System where health service level, including specialised health services was the second carried out by a specialist or specialist dentist who uses the health knowledge and technology, including specialised. Second-level health services can only be provided upon referral from the first level of health care, but in the case of kegawat daruratan can be directly served in Emergency Unit (ER) with no references (1) veins. Based on the above RS UMM have to figure out the proper marketing strategy so that many patients will be especially patient BPJS chose RS UMM as the Hospital of choice for medical treatment. RS UMM as second-level hospitals have done a collaboration with some of the first-level health facilities around the Poor areas can be found in annex 1.

The number of patient visits RS on UMM BPJS from January up to April 2017 improved from 91 patients be 213 patients, but in May until July decline visits around 42\%. Visits declining and low bias affects DRILL RS UMM due to low visitation then Rerate the community has yet to utilize properly the hospital as a place of reference and medical treatment. The number of hospitals that provide services competitor BPJS and future in 2019 all mandatory Indonesia society became the participants of the BPJS aka party RS UMM have to know what factors are low occupational mepengaruhi (the use of) hospitalization RS UMM by the BPJS patients so that later the hospital could fix and improve returns the number of visits the patient BPJS. Several approaches can be used to find out the factor that affects the DRILL a hospital among other utility analysis, market analysis (marketing) approach and analysis system. To view the factors of low use of hospitalization by the BPJS RS patients UMM used with marketing analysis that is using a marketing strategy by which consist of marketing mix of product, price, place, promotion, people, physical evidence and process.

The number of visits of patients who experienced a decrease in the BPJS using inpatient HOSPITAL UMM then the hospital should know the factors that affect the low okupsi (the use of) rawat by patients BPJS.

Based on the explanation on the background above, researchers interested in conducting research with the title influence of quality of service and the implementation of the policy of the administration of the hospital inpatient patients return towards the satisfaction of patients BPJS class III hospital Muhammadiyah University of Malang.

\section{METHODS}

Quantitative research design that is descriptive. Research on variable i.e. the influence of quality of service and the implementation of the policy as the independent variable and patient satisfaction as 
the dependent variable BPJS. Population research i.e. whole health BPJS patients who underwent hospitalization on 15th October - November 15, 2018. Samples taken by random sampling technique as much as 92 respondents. The data collected by the instruments and questionnaires processed in coding, editing, tabulating and scoring as well as tested with linear regression test.

\section{RESULT}

\section{Bivariat Analysis}

Table 1.Bivariate analysis (pearson correlation) influence the marketing strategy against occupasi in hospital Muhammadiyah University of Malang November 2018 ( $n=92)$

\begin{tabular}{ccc}
\hline Criteria & Correlation Coeffisien Value & P value \\
\hline Product & 0,629 & 0,000 \\
\hline Price & 0,491 & 0,000 \\
\hline People & 0,434 & 0,000 \\
\hline Place & 0,534 & 0,000 \\
\hline Proses & 0,518 & 0,000 \\
\hline
\end{tabular}

Based on the correlation of Pearson's test results indicate the value of the p value to 5 components of a marketing strategy $<0.05$ so that this shows that there is an influence of the marketing strategy against occupasi in hospital Muhammadiyah University of Malang.

\section{Partially Analiysis}

Tabel 2.Liner regersi analysis of partially (test $t$ test) influence the marketing strategy against occupasi in hospital Muhammadiyah University of Malang November $2018(\mathrm{n}=92)$

\begin{tabular}{ccc}
\hline Criteria & $\mathrm{t}$ test value & $\mathrm{P}$ value \\
\hline Product & 5.467 & .000 \\
\hline Price & 3.374 & .001 \\
\hline People & 3.707 & .000 \\
\hline Place & 2.923 & .004 \\
\hline Proses & 2.077 & .001 \\
\hline
\end{tabular}

Based on the results in table 2 shows that the value of $p$ value on components of marketing strategies (product, price, place, people, and processes) of less than 0.05 so that partially independent variables or own marketing strategies (product, price, people, place, and the process) affect patient occupasi.

\section{Simultaneously Analysis}

Tabel 3.Multivariate Analysis simultaneously or synchronously influence marketing strategy against occupasi in hospital Muhammadiyah University of Malang November $2018(\mathrm{n}=92)$

\begin{tabular}{llrrrrr}
\hline Model & & Sum of Squares & df & Mean Square & F & Sig. \\
\hline 1 & Regression & 9.560 & 5 & 1.912 & 33.434 & $.000^{\mathrm{b}}$ \\
& Residual & 4.918 & 86 & .057 & & \\
& Total & 14.478 & 91 & & & \\
\hline
\end{tabular}

a. Dependent Variable: Occupasi

b. Predictors: (Constant), Proses, People, Price, Product, Place

Based on the results in table 3 show that the significance of value shows the value $=0.000$ meaning can be expressed so that 0.05 < simultaneously or synchronously independent variable marketing strategies (product, price, place, people, and processes) mempengarui occupasi the patient. 


\section{Determination Coefficient Analysis}

Tabel 4.Analysis of coefficient of determination of the influence of marketing strategy against occupasi in hospital Muhammadiyah University of Malang November $2018(\mathrm{n}=92)$

\begin{tabular}{|c|c|c|c|c|c|}
\hline Model & $\mathrm{R}$ & R Square & $\begin{array}{l}\text { Adjusted R } \\
\text { Square }\end{array}$ & $\begin{array}{l}\text { Std. Error of the } \\
\text { Estimate }\end{array}$ & Durbin-Watson \\
\hline 1 & $.813^{\mathrm{a}}$ & .660 & .641 & .239 & 1.514 \\
\hline
\end{tabular}

Table 4 explains that the value R Square (R2) of $0.66060 .6 \%$ or that shows contributions from independent variable marketing strategies (product, price, place, people, and processes), while the rest was $39.4 \%$ in influence by other factors not present in the This research model. Multiple correlation coefficient is used to measure the keeratan relationship between the dependent and independent variables. Multiple correlation coefficient indicated by value $(\mathrm{R})$ of $0.81381 .3 \%$ or indicating that the independent variable of the marketing strategies (product, price, place, people, and processes) of occupasi patients have close links.

\section{DISCUSSION}

\section{Marketing strategy done by Muhammadiyah University of Malang Hospital in terms of product components}

The characteristics of the strategy pemasran retrieved data nearly half of respondents said the hospital's marketing strategy includes a pretty good strategy as much as 45 respondents (49\%) and a small part of States including strategy. Based on cross-tabulations between product and interest occupasi obtained the marketing strategy in the data components of the product are given by the service of RS interest largely affect the UMM occupasi patients by as much as 57 respondents (100\%).

Marketing strategy according to Tjiptono (2008) is a plan that lays out the company's expectations will be the impact of various marketing programs or activities against the demand for a product or product line in specific target markets. Marketing program includes marketing actions that can affect the demand for the product, such as in the event of a price change, modify the advertising campaign, designing special promotions, determine the choice of distribution channels, and others . According to Anggreni (2011) one of the marketing strategies that can be applied in an effort to increase consumer interest and kan kepuasaat, Subscriber is through is the application of marketing mix (the marketing mix). Marketing mix (markting mix) is a set of variable-variable marketing combined to get the required responses right on target markets, one of which is the pemasran product mix components..

The results of this study indicate that the product offered or provided by RS UMM has a positive value in the minds of patients because the patients perceive that services provided by RS UMM is in compliance with the expectations of patients and service the good enough according to $\mathrm{p}$ [diataranya asien nurse response quite fast in delivering action on the patient, and the clerk was quite gracious in receiving and providing services.

\section{Marketing strategy done by Muhammadiyah University of Malang Hospital in terms of price components}

The characteristics of the strategy pemasran retrieved data nearly half of respondents said the hospital's marketing strategy includes a pretty good strategy as much as 45 respondents (49\%) and a small part of States including strategy. Based on cross-tabulations between product and interest occupasi obtained the marketing strategy in the data components of the product are given by the service of RS interest largely affect the UMM occupasi patients by as much as 57 respondents (100\%).

According to Kotler (2014) the price (price) in the determination of the price for tourism products offered must be balanced with the purchasing power of the market and attractive to prospective consumers. Conothnya about the selling price of the product kepariwisataanya, Bali offers its tourism products with a relatively cheaper price compared to other destinations-destinations that are located in Southeast Asia, such as Malaysia, Singapore, and Thailand.

The results of this research show that the price of the services offered by the manaemen RS UMM relative equal to other hospitals, there is little difference in terms of facilities received by the patient or 
the cost difference is also not too far away. This may be a consideration for patients in making informed decisions to obtain health services from hospitals in accordance with the hopes and desires of the patient. The price offered by the RS UMM affect interest in patients receiving occupasi services at RS UMM.

\section{Marketing strategy done by Muhammadiyah University of Malang Hospital in terms of people components}

The characteristics of the strategy pemasran retrieved data nearly half of respondents said the hospital's marketing strategy includes a pretty good strategy as much as 45 respondents (49\%) and a small part of States including strategy. Based on cross-tabulations between people and data obtained occupasi interests of the marketing strategies in the component service officer or browse RS UMM most affect patient occupasi interest as much as 52 respondents $(94.5 \%)$.

According to Kotler in Armstrong (2008) States Personnel (people) involvement of all actors (Government, community, private parties, employees and contact other people) in the activities of the Ministry of health is indispensable, especially in affected patient perception, be it through government regulation-regulation has been established, the community and stake holder who carry out their best, be it keep, maintain the facilities and surroundings, so it created a cosy and safe.

The results of this research show that with people in marketing strategies affect patient occupasi interest in RS UMM because, officers or personal service on a health services is also one of consideration of patients as an alternative to receiving health care services. The better and friendly staff who deliver services will be increasingly interested patients to choose where the Ministry and vice versa if the officer or personal are not too friendly, and less attention to the patient then it is likely the patient will not be attracted to visits or spot checks on the health service.

\section{Marketing strategy done by Muhammadiyah University of Malang Hospital in terms of place components}

The characteristics of the strategy pemasran retrieved data nearly half of respondents said the hospital's marketing strategy includes a pretty good strategy as much as 45 respondents (49\%) and a small part of States including strategy. Based on cross-tabulations between place and interest data obtained by occupasi marketing strategy in place or location components RS UMM and the facilities in it mostly affects interest occupasi patients as much as 59 respondents $(95.2 \%)$.

According to Kotler (2014) place (place) in the market the product through chanel chaneldistribution channels so that it can form the image and make it easier to attract patients, for example, by working with the agency, radio or also form a place of service the nayman and beautiful to be an attraction for patients in performing the medical examination.

The results of this study indicate that the place provided by the management of RS UMM became one part of a good marketing strategy if the place is managed properly, meaning place of the health service and a comfortable, cool and not too many good voice nor air pollution will make its own interest for patients to choose the venue as a place to receive health care services, for the respondent because they need a comfortable and quiet place so they can soon recover from health problems that are being experienced

\section{Marketing strategy done by Muhammadiyah University of Malang Hospital in terms of proses components}

The characteristics of the strategy pemasran retrieved data nearly half of respondents said the hospital's marketing strategy includes a pretty good strategy as much as 45 respondents (49\%) and a small part of States including strategy. Based on cross-tabulations between the process and the data obtained occupasi interests of the marketing strategies in the process component or service of process at RS mostly affects the interest of UMM occupasi patients by as much as 63 respondents $(92.6 \%)$. According to Kotler (2014) process management in this important management process also carried out research on consumer behavior in purchasing the tourism product, so the marketing process so more competitive. These activities in the form of simplicity in the procedures of business contacts who do all the components management and travelers so that they can convince tourists to want to purchase products offered through the parwisata contact pskologis and interpersonal contacts, for example, 
simplify the transaction process, write the policies regarding the handling of service, address the keluhankeluhan tourists and others.

The results showed that the process of the management of service shown by RS UMM in providing health services already meet the expectations and wishes of the patient and in accordance with the standard of service that exists so that it can affect the interest patients in the repeated visits to receive service from RS UMM back. Management process that does not kink and can be easily implemented patient can be one alternative reference patient in taking a decision to receive a health service.

\section{The level of interest in the use of okupansi hospitalization by the BPJS patients in hospital Muhammadiyah University of Malang.}

Characteristics of respondents based on occupasi data obtained by most of the respondents have a good interest to continue using the services of inpatient care in RS UMM as much as 74 respondents $(80 \%)$

BOR is a number that indicates the percentage of the level of use of bed at a certain unit of time in the inpatient unit (ward). Standard value ideal Barber Johnson according to Health RI for BOR 60$85 \%$. If the value of the BOR more than $85 \%$ the Ministry run by doctors, nurses and other health workers are less effective, it can be due to a high workload), b) work space is limited but the use of the bed which took place in continuously increasing quality, c) patients receiving treatment are worth the need. Benefits calculation BOR is to know the level of the use of a hospital bed. BOR a low number to a lack of use of the facilities of the hospital care by the Community (Kurniawan, et al, 2010)

The core of the inpatient services is a service of care on the patients themselves. The nurse on duty and affecting patients is the spearhead of the inpatient service so that the principal concern of hospital management, namely the form of nurse services provided by nurses. Nurses should understand what an major base a patient decided to use inpatient services at the hospital, which is a relief. The hospital should be able to find the essential needs are hidden behind each service. The goal is not to another in order to profit or benefit from a Ministry, not just its attributes or features, can be explained on the consumer. BOR figure associated with the long day care. The number of days of treatment which the lower then the lower the value of the existing BOR. The low numbers of day care can be caused by the lack of usage of the bed also because patient hospitalization to feel uncomfortable so that the patient feels that she must be moved to another hospital care.

\section{Relationship Marketing strategies conducted by the hospital Muhammadiyah University of Malang with interest the utilization (occupational) inpatient patient BPJS.}

Based on the results in table 2 shows that the value of $p$ value on components of marketing strategies (product, price, place, people, and processes) of less than 0.05 so that partially independent variables or own marketing strategies (product, price, people, place, and the process) affect patient occupasi. Based on the results in table 4.2 shows that show the value of significance value $=0.000$ which means less than 0.05 so that it can be expressed simultaneously or synchronously independent variable marketing strategies (product, price, people, place, and the process) mempengarui occupasi the patient. Table 4.3 explains that the value R Square (R2) of $0.66060 .6 \%$ or that shows contributions from independent variable marketing strategies (product, price, place, people, and processes), while the rest was 39.4\% in influence by other factors that do not exist in this research model. Multiple correlation coefficient is used to measure the keeratan relationship between the dependent and independent variables. Multiple correlation coefficient indicated by value $(\mathrm{R})$ of $0.81381 .3 \%$ or indicating that the independent variable of the marketing strategies (product, price, place, people, and processes) of occupasi patients have a close relationship.

The marketing mix (the marketing mix) is a set of marketing tools the company used to constantly achieve the purpose of marketing in the target markets (Kotler, 2014). S (2008) stated "the marketing mix strategy guide refers to the product, distribution, promotion and pricing are uniquely designed to produce a mutually satisfying exchanges with the intended market". The marketing mix is every effort can be made by a company to influence their target market demand towards products/services. The possibility that activity can be formulated into four variables, by McCarthy referred to as $5 \mathrm{p}$ of 
marketing: product (product), the price (price), place (place), a process (process) and promotion (promotion) (Kotler and Keller, 2014).

The marketing mix is judged negatively by the respondent giving indication that service marketing efforts conducted by the hospital management did not go well. A set of components of marketing tools developed by RS UMM didn't go according to expectations. An assortment of reasons why it could happen, that issue would certainly come from the problems that arise from each of its components. So the overall affect on existing marketing mix at RS UMM, in the end that is feeling the effects of the marketing mix is a patient or use of services RS UMM himself. The existence of a negative perception by the patient about marketing strategy indicated that dissatisfaction received the patient and can make patients feel uncomfortable in accepting hospital service, so this affects patients in using the services of the hospital or the patient can switch hospitals.

\section{CONCLUSION}

Characteristics of pemasran strategy in Muhammadiyah University Hospitals of Malang almost half of respondents said the hospital's marketing strategy includes a pretty good strategy as much as 45 respondents (49\%). Characteristics of respondents based on occupasi data obtained by most of the respondents have a good interest to continue using the services of inpatient care in a Muhammadiyah University Hospitals of Malang as much as 74 respondents $(80 \%)$

Marketing strategy in the components of the product are given by the officer at Muhammadiyah University Hospitals of Malang most affect patient occupasi interest as much as 57 respondents (100\%). The marketing strategy in the components of the price or the price given by the Muhammadiyah University Hospitals of Malang most affect patient occupasi interest as much as 59 respondents $(93.7 \%)$.

Marketing strategies in component services officer or browse Muhammadiyah University Hospitals of Malang most affect patient occupasi interest as much as 52 respondents $(94.5 \%)$. Marketing strategies in place or location components Muhammadiyah University Hospitals of Malang and the facilities in it mostly affects interest occupasi patients as much as 59 respondents $(95.2 \%)$.

The marketing strategy in the process component or service of process in Muhammadiyah University Hospitals of Malang most affect patient occupasi interest as much as 63 respondents $(92.6 \%)$. There is a relationship between the strategy of marketing (product, price, place, people, and processes) against occupasi the patient with a category of relation is shown the value of the coefficient of determination of 0.813 or $81.3 \%$.

\section{SUGGESTION}

\section{For Hospital Muhammadiyah University Hospitals of Malang}

For hospitals, many things that have to be addressed in the framework of the development of marketing activities. Evaluation of the hospital's marketing tools is the first step that must be done, so will note the success of the marketing tools that are already developed. Hospital management must be able to optimize all the advantages to hospitals to cover the shortage of which is also attached to the hospital, maximizing every opportunity and anticipate threats arising from the competition.

Conformity of the quality of hospital service with rates pegged is the first step that must be addressed. Improvement of the quality of care services become a necessity if the hospital requires high rates of hospitalization.

\section{For the officer Officers}

For the officer Officers need to increase understanding of how the services should be given in patients who are good enough quality, such as the granting of fast service through 
participation in training, seminars and coaching as well as from books readings and more motivated again in doing health care on the patient.

\section{For the next Researcher}

For the next researcher who did similar studies are expected to conduct research that is more complex and extensive variables as well as the number of sampelnya so that the research results are more developed and can be menignkatkan science and technology in the field of management of hospital services.

\section{REFERENCE}

Anggreni, 2014, Analisis Kualitas Pelayanan di Restoran Saung Mirah Bogor

Basu, Swastha. 2012. Manajemen Penjualan, Edisi 3, Yogyakarta, BPFE.

Fatihudin, Didin,2012.Metode Penelitian untuk Ilmu Ekonomi,Manajemen dan Akuntansi : dari Teori ke Praktek. Surabaya : penerbit PPs UM Surabaya.

Jones R. Hospital Bed Occupancy Demystified and Why Hospital of Different Size and Complexity

Must Run at Different Average Occupancy. Journal of Healthcare Management. 2011;17(6):242-8

Kurniawan A, Lestari T. 2010. Analisis Pemanfaatan Data Sensus harian RAwat Inap untuk Pelaporan Indikator Pelayanan RAwat Inap di Rumah Sakit Umum Daerah dr. Soeroto Ngawi. Rekam Medis.

Hasan, M. Iqbal. 2002. Pokok-pokok Materi Metodologi Penelitian dan Aplikasinya. Bogor : Ghalia Indonesia.

Anita Anggraeni dan Hartiwi Prabowo, 2011, Analisis Pengaruh Persepsi Kualitas dan Citra Merek terhadap Kepuasan Pelanggan dan Dampaknya pada Pembelian Ulang (Studi Kasus :

Pelanggan Majalah Mix di Jakarta Selatan, Journal E Prints Binus, 2347

Kotler, Philip dan Armstrong, Gary. 2008. Principles of Marketing (Fourteenth Edition). England: Pearson Education Limited

Kotler, P., dan K. L. Keller. 2014. Manajemen Pemasaran. Edisi Ketiga belas. Jilid 1. Jakarta : Erlangga

Kotler., 2014. Manajemen Pemasaran. Edisi 1 dan 2. Jakarta. Prenhllindo

Lupiyoadi, Rambat. 2014. Manajemen Pemasaran Jasa. Edisi 3. Jakarta:Salemba.

Sugiyono. 2012. Metode Penelitian Kunatitatif Kualitatif dan R\&D. Bandung : Alfabeta.

Tjiptono, Fandy. 2014. Strategi Pemasaran. Yogyakarta: Penerbit Andi.

UU RI Badan Penyelenggaraan Jaminan Sosial. No. 24 Tahun 2011

Peraturan Badan Penyelenggara Jaminan Sosial Kesehatan. Penyelenggaraan Jaminan Kesehatan No. 1 Tahun 2014

PERMENKES RI. Standar Tarif Pelayanan Kesehatan. NO. 59 Tahun 2014 